\title{
28
}

\section{Meeting the Potential of Alternative Remedies in Australian Defamation Law}

\section{Robyn Carroll ${ }^{1}$ and Catherine Graville ${ }^{2}$}

\section{Introduction}

The primacy of damages as the remedial response to breaches of civil obligations sometimes obscures the role in law of other responses to wrongdoing, including corrections and apologies. In defamation law, the case for alternative remedies is particularly strong and has been the subject of judicial, academic and law reform urgings over the years. At the same time, efforts to achieve fair and effective remedies without the inevitable delays of litigation have resulted in developments in dispute resolution processes and defences aimed at quicker resolution of defamation disputes. There are a number of ways in which the law affects the extent to which alternative processes and remedies achieve the remedial objects of defamation law.

This chapter reviews the recommendations for alternative remedies made in law reform processes in Australia since the 1970s. We refer, in particular, to the offer to make amends provisions introduced by state and territory defamation laws that encourage non-litigious and prompt resolution of

1 Professor of Law, University of Western Australia.

2 BA, LLB (Hons), University of Western Australia. 
defamation disputes and create a defence when a reasonable offer by the publisher is rejected by an aggrieved person. We conclude that alternative remedies and the offer to make amends defence play an important role in Australian defamation law. We recommend, in particular, that the offer to make amends provisions should require a 'sufficient apology' as a term of an offer as well as a 'reasonable correction'.

\section{The Potential of Alternative Remedies and Processes for Defamation}

The effectiveness of damages as a remedy for defamation has long been doubted. ${ }^{3}$ There is evidence that the primary interest of most plaintiffs, immediately after a defamatory publication, is the effective restoration of their reputation, rather than damages. ${ }^{4}$ Law reform commissions report that corrections and sometimes apologies are what most plaintiffs seek, initially at least. ${ }^{5}$ It can take years for a claim to be heard and it is doubtful whether the result becomes generally known to readers of the original defamatory statement. As a result, to a successful plaintiff an award of damages 'is not a restoration of his reputation but a money reparation for his loss'. ${ }^{6}$

There have been numerous proposals emanating from law reform bodies and government reports aimed at encouraging defendants to take prompt steps to respond to a complaint by a person that they have defamed, and for plaintiffs to settle on fair and reasonable terms. These include a defence of prompt and adequate correction, ${ }^{7}$ giving defendants an option of either paying damages or publishing a correction, ${ }^{8}$ provision of an opportunity

3 Australian Law Reform Commission, Unfair Publication: Defamation and Privacy, Report No 11 (Australian Government Printing Service) [253] ('ALRC, Unfair Publication').

4 Randall P Benzanson, 'The Libel Suit in Retrospect: What Plaintiffs Want and What Plaintiffs Get’ (1986) 74 California Law Review 789, 791.

5 For example, New South Wales Law Reform Commission, Defamation, Report 75 (1995), [8.1] ('NSWLRC, Defamation').

6 ALRC, Unfair Publication, [253].

7 NSWLRC, Defamation, Ch 8.

8 Standing Committee of Attorneys-General Working Group of State and Territory Officers, Proposal for Uniform Defamation Laws (July 2004) 29 ('SCAG Proposal'). 
for reply ${ }^{9}$ and the defence of offer to make amends. ${ }^{10}$ Other proposals provide for court orders in the form of correction orders, ${ }^{11}$ including a correction order as an alternative to damages, ${ }^{12}$ vindication orders, ${ }^{13}$ declarations of falsity, ${ }^{14}$ and retraction and apology orders ${ }^{15}$ in addition to damages, declarations and injunctions. There have also been calls for a right of reply in certain circumstances. ${ }^{16}$

Further proposals note the importance, and increased use, of mediation and case management of litigated matters, the availability of strike-out proceedings, ${ }^{17}$ and less costly proceedings to dispose of unmeritorious defamation claims. ${ }^{18}$

\section{The Legislative Response to the Call for Alternative Remedies and Processes}

\section{A. Reform under the uniform defamation laws}

Between 2005 and 2006, uniform defamation laws were enacted across all Australian jurisdictions. ${ }^{19}$ The objects of the Defamation Act 2005 (NSW) (the Act), stated in s 3, include:

9 ALRC, Unfair Publication, [294].

10 New South Wales Law Reform Commission, Defamation, Report No 11 (1971) [40]; New South Wales Law Reform Commission, Defamation, Report 75 (1995) [8.21]-[8.24]; Australian Capital Territory Community Law Reform Committee, Defamation Report, Report No 10 (1995) 18-19; Attorney-General's Task Force for Defamation Law Reform (NSW), Defamation Law Proposals for Reform in NSW (September 2002) 6-7.

11 ALRC, Unfair Publication, [258]; Australian Government, Attorney-General's Department, Revised Outline of a Possible National Defamation Law, July 2004, 34 ('A-G's Revised Outline').

12 SCAG Proposal, 29.

13 Attorney-General (ACT), Defamation Report in the ACT (September 1998) 6-8.

14 NSWLRC, Defamation, 103.

15 ALRC, Unfair Publication, [257]; see also Dario Milo, Defamation and Freedom of Speech (Oxford University Press, 2008) 273.

16 ALRC, Unfair Publication, [156], [178], [294]; A-G's Revised Outline, 32; see also John Fleming, 'Retraction and Reply: Alternative Remedies for Defamation' (1978) 12 University of British Columbia Law Review 15; Dario Milo, Defamation and Freedom of Speech (Oxford University Press, 2008) Ch VIII.D.2; Patrick George, Defamation Law in Australia (LexisNexis Butterworths, $2^{\text {nd }}$ edn, 2012) Ch 40; David Rolph, Defamation Law (Lawbook Co, 2016) Ch 17.

17 A-G's Revised Outline, 29-30.

18 Ibid. 31.

19 The Defamation Act 2005 (NSW) is representative of the uniform defamation laws enacted in each of the Australian states and territories. The national laws are enacted by the: Defamation Act 2005 (Qld); Defamation Act 2005 (SA); Defamation Act 2005 (Tas); Defamation Act 2005 (Vic); Defamation Act 2005 (WA); Civil Law (Wrongs) Act 2002 (ACT) and the Defamation Act 2006 (NT). 
(c) to provide effective and fair remedies for persons whose reputations are harmed by the publication of defamatory matter, and

(d) to promote speedy and non-litigious methods of resolving disputes about the publication of defamatory matter.

Consistent with s 3(c), there were significant amendments aimed at encouraging vindicatory responses to defamatory publications other than damages. ${ }^{20}$ Subsections 38(1)(a)-(b) respectively provide for evidence of published apologies and corrections to be admitted in mitigation of damages. Section 20 provides that an apology is not an express or implied admission of liability or admissible as evidence of fault or liability. This section 'is designed to encourage defendants to say sorry ${ }^{21}$ and is consistent with the Commonwealth Attorney-General Department's conclusion that defendants are more likely to apologise for, or retract, defamatory statements if their apology or retraction is not taken to be an admission of liability. ${ }^{22}$ There were also significant amendments introduced by the Act to the damages remedy, which created a cap on defamation damages for non-economic loss and abolished exemplary or punitive damages. ${ }^{23}$ There appears to be strong support for uniform defamation laws in Australia although differing views remain as to the appropriate liability rules, defences and damages available. ${ }^{24}$

\section{B. Alternative remedies (remedies other than damages)}

Despite the proposals outlined above, no provisions were introduced under the uniform defamation laws to confer power on the courts to order or to recommend alternative remedies. Plaintiffs need therefore to rely on negotiated outcomes and offers of compromise to achieve these outcomes, or use the offer to make amends provisions.

\footnotetext{
20 Defamation Act 2005 (NSW) ss 20, 38(1)(b).

21 NSW Hansard, Defamation Bill, 18 October 2005, the Hon Henry Tsang, Parliamentary Secretary, referred to in Hunt v Radio 2SM Pty Ltd (No. 2) [2010] NSWDC 43, [36] (Gibson DCJ) ('Hunt').

22 A-G's Revised Outline, 33.

23 Part 4, Div 3, 'Remedies'.

24 See submissions to NSW Department of Attorney-General and Justice Review of the Defamation Act 2005 ('NSW Review'). This five year review is required by s 49 of the Act. The submissions are available at www.justice.nsw.gov.au/justicepolicy/Pages/lpclrd/lpclrd_consultation/lpclrd_stat_ reviews.aspx\#ReviewofDefamationAct2005.
} 


\section{The offer to make amends}

The offer to make amends provisions in Pt 3 Div 1 of the Act create a mechanism that aims to encourage parties to settle a defamation claim quickly without a trial and on terms that recognise the value of remedial responses other than the payment of damages, seemingly consistent with the objects in s 3(c)-(d). Broadly speaking, these provisions allow a publisher (referred to here as 'defendant') to offer to the aggrieved person (referred to here as 'plaintiff') to publish a correction and pay expenses, and, optionally, to publish an apology and to pay compensation. If the plaintiff accepts the offer to make amends, they are barred from commencing or continuing an action in defamation. ${ }^{25}$ If the plaintiff does not accept the offer, then in subsequent proceedings the defendant may rely on the fact of having made a reasonable offer as a complete defence. ${ }^{26}$ If the defendant is successful at trial, the plaintiff may also have to pay indemnity costs for having unreasonably failed to accept a reasonable offer to make amends. ${ }^{27}$ If the plaintiff is successful, the defendant may have to pay indemnity costs for unreasonably failing to make a settlement offer. ${ }^{28}$

It is difficult to calculate how often the offer to make amends provisions are being used because of the private nature of settlement. The volume of reported cases considering offer to make amends provisions to date is small but there are indications that the provisions are being used more than under previous legislation. The provisions have been described as a 'simpler and more streamlined process of offer to make amends' 29 and as a 'revolution' in defamation law. ${ }^{30}$ Suggestions have been made to address uncertainties in their operation. ${ }^{31}$ It has also been commented judicially that the provisions operate to the disadvantage of plaintiffs over defendants. ${ }^{32}$

\footnotetext{
25 Defamation Act 2005 (NSW) s 17(1).

26 Ibid. s 18(1).

27 Defamation Act 2005 (NSW) ss 40(2)(b), (3). This is the same inquiry as to whether an offer is 'reasonable' for the purposes of the defence under s 18(1): Sleeman v Tuloch Pty Ltd (No 4) [2013] NSWDC 111 (19 July 2013) 10 [25] (Gibson DCJ) ('Sleeman').

28 Defamation Act 2005 (NSW) s 40(2)(a). A 'settlement offer' includes a reasonable offer to make amends: s 40(3).

29 Hunt, n 18 [36].

30 Andrew Kenyon, 'Six Years of Australian Uniform Defamation Law: Damages, Opinion and Defence Meanings' (2012) 35 University of New South Wales Law Journal 31, 35.

31 See, for example, NSW Bar Association, 'Submission to the New South Wales Department of Attorney-General and Justice, Review of Defamation Act 2005', undated, 19; Matthew Collins, 'Five Years On: A Report Card on Australia's National Scheme Defamation Laws' (2011) 16 Media and Arts Law Review 317, 322-23.

32 Pingel v Toowoomba Newspapers Pty Ltd [2010] QCA 175 (16 July 2010) 21 [62]-[63] ('Pingel); Pedavoli v Fairfax Media Publications Pty Ltd (2014) 324 ALR 166, 173) ('Pedavoli').
} 


\section{Meeting the Potential of Alternative Remedies and Processes in Australian Defamation Laws}

Based on past experience and concerns it seems unlikely that consensus will be reached easily across governments on an expansion of remedial alternatives. Instead, the offer to make amends provisions continue the Anglo-American preference for attaining desirable objectives by 'rewards rather than force'; ${ }^{33}$ that is, by creating a defence to a defamation claim when a reasonable offer has been made to a plaintiff, rather than compelling, for example, a right of reply. These provisions seek to balance the objective of effective and fair remedies with promoting speedy and non-litigious resolution of disputes.

\section{A. The potential for further development of alternative remedies}

There is merit in ongoing consideration of the remedies of retractions and apologies, corrections, rights of reply and declarations of falsity. ${ }^{34}$ Realistically, legislation for a right of reply and for corrections and apologies is unlikely as the legislatures have made it clear they prefer to encourage and not compel these remedial actions. In the absence of legislation expressly conferring power on the court to make these orders, courts are unlikely to grant them as common law remedies, in part due to concerns about interference with a publisher's freedom of expression..$^{35}$

\section{B. Correction and apology as required components}

Given the unlikelihood that more extensive remedial powers will be enacted in the near future, the offer to make amends provisions need to strike a fair balance between the s 3(c)-(d) objects. At present, s 15(1)(d) of the Act mandates the inclusion of a 'reasonable correction' in an offer to make amends. If the defendant does not include an offer to publish

33 Fleming, n 16, 24.

34 For support, see Rolph, n 16, [17.110]-[17.1.30]; Milo, n 16, 269-78.

35 Summertime Holdings Pty Ltd v Environmental Defender's Office Ltd (1998) 45 NSWLR 291, 297; Robyn Carroll, 'Beyond Compensation: Apology as a Private Law Remedy' in Jeffrey Berryman and Rick Bigwood (eds), The Law of Remedies: New Directions in the Common Law (Irwin Law, 2010) 323, 370-71. 
a reasonable correction, then the purported offer to make amends will be invalid. ${ }^{36}$ By contrast, the absence of an offer to publish an apology will only be relevant to the 'reasonableness' of the offer in determining whether a defence exists if the offer is rejected and for the purposes of awarding indemnity costs (s 40). The plaintiff can only obtain an offer of apology by negotiation with the defendant. If the plaintiff proceeds with litigation, the defendant can rely on alternative defences, not just their offer to make amends. ${ }^{37}$

Section 38(1)(a) of the Act recognises the ability of an apology about the publication of a defamatory matter, as well as a published correction, to mitigate damage to a plaintiff's reputation and injured feelings. The Act makes a distinction in $\mathrm{s} 15$ between 'corrections' and 'apologies' (though neither term is defined) notwithstanding that these terms are often used interchangeably and correction sometimes is incorporated within apology. ${ }^{38}$ George notes that, '[i] n practice, apologies are usually related to the meaning of the words, corrections usually relate to misstatements of facts' ${ }^{39}$ Making amends for publication of a matter that is or may be defamatory' (s 13(1)) must surely involve more than correction of a misstatement of fact. In Szanto $v$ Melville, Kaye J reasoned that a correction for s 15(1)(e) requires at the very least a 'plain acknowledgement that the defendant defamed the plaintiff..$^{40}$ The line between correction and apology in this context is not clear, as acknowledgement that a publication is defamatory is more than a correction of fact.

The offer to make amends defences in the UK and Ireland, which have similar purposes, require a 'suitable correction' and a 'sufficient apology'. ${ }^{41}$ In the absence of a broad statutory definition of 'correction' in the Act

36 Szanto v Melville [2011] VSC 574 (4 November 2011) 57 [169] (Kaye J).

37 Contrast the operation of the offer to make amends defence in the UK and Ireland where reliance on the offer to make amends defence precludes reliance on alternative defences.

38 See, for example, Pedavoli, n 32, 180. The A-G's Revised Outline, n 11, equates correction with apology and proposed that 'apologies' be defined to include retractions and voluntary corrections: 33 . Contrast the NSWLRC, Defamation, n 5, which defines a 'correction' as a 'collective term for retractions, apologies and replies ... [which] recognises that the purpose of all three forms of expression is to correct public misconceptions as to the plaintiff's reputation, and as to the true facts': 14 [2.14].

39 George, n 16, 419, who concludes that the usefulness, therefore, of correction orders may in practice be limited.

40 [2011] VSC 618, 7-8.

41 Defamation Act 1996 (UK) c 31, s (2)(1); Defamation Act 2009 (Ire) s 22(5)(a). This also reflects the fact that reliance on the defence created by these provisions necessarily involves conceding that the publication was defamatory: Nail v News Group Newspapers Ltd [2004] EMLR 362 paras 34-36; [2005] 1 All ER 1040, [19] CA. 
in Australia that incorporates apology, we submit that s 15 similarly should require both a 'reasonable correction' and a 'sufficient' apology or an apology that is 'reasonable' in the circumstances. ${ }^{42}$ What constitutes a sufficient apology and what will be a reasonable offer for purposes of $s$ 18(1) of the Act in each case will be highly fact sensitive and judged in light of all of the circumstances. Depending on the circumstances, it may be sufficient to apologise for any offence caused by the publication. ${ }^{43}$ In more serious cases, acknowledgement of the falsity of the defamatory statement may be necessary. ${ }^{44}$ The defence that arises by making a reasonable offer to make amends, after all, is based on an offer to make amends for harm caused by publication of matter that is incorrect. Further, ss $19^{45}$ and 20 are intended to address concerns that an offer of apology will be used adversely as evidence of an admission of fault.

Finally, if there is a concern that this amendment would be tantamount to compelling a publisher of matter that 'is or may be defamatory' to apologise, this is countered by the fact that a defendant is not under any compulsion to offer an apology (or a correction for that matter). Use of these provisions is optional. The choice not to use them may detract from the 'speedy and non-litigious' object in the Act but that needs to be balanced against the 'effective and fair remedies' object.

\section{Less costly proceedings for minor matters}

Concerns remain about the high cost of proceedings to resolve some matters relating to offer to make amends proceedings. ${ }^{46}$ Suggestions that merit attention include that the Act be amended to provide for lower cost court options ${ }^{47}$ and consideration be given to conferring jurisdiction on

42 See also Robyn Carroll and Jeffrey Berryman, 'Making Amends by Apologising for Defamatory Publications - Developments in the $21^{\text {st }}$ Century', in Kit Barker, Ross Grantham and Karen Fairweather (eds), Private Law in the 21st Century (Hart Publishing, 2017) Ch 24.

43 For example, Sleeman, n 27. It was also considered reasonable in this case to offer the apology without an offer to pay compensation. The text of the apology is available at Sleeman v Tuloch Pty Ltd (No 4) [2013] NSWDC 111.

44 For example, Ell v Milne (No 9) [2014] NSWSC 489 (11 April 2014) 10 (McCallum J).

45 See Pingel, n 32, [24]-[25] (Fraser JA), 41-42 [165]-[166], [169]-[170] (Applegarth J).

46 Bridgette Styles, 'The Power of a Timely Apology' (2013) 51(7) Law Society Journal 24.

47 See Hunt, n 21, [56]. 
low cost tribunals. ${ }^{48}$ The outcomes of a review of the Act conducted by the NSW Department of Attorney-General and Justice may well provide other recommendations relating to the offer to make amends defence. ${ }^{49}$

\section{Conclusion}

Through common law principles and now a number of provisions of the Act, the law attaches importance to prompt, fair and effective remedial responses to defamatory publications. The private nature of settlement, however, makes it difficult to calculate the rate of use and satisfaction with the laws and provisions that result in matters not coming to court. The primary aim of this chapter is to draw attention to aspects of the Pt 3 Div 1 provisions that will promote object 3(c) more coherently and consistently.

48 NSW Review, n 24, NSW Bar Association Submission.

49 This five year review is required by s 49 of the Act. The submissions to the Review are available at: www.justice.nsw.gov.au/justicepolicy/Pages/lpclrd/lpclrd_consultation/lpclrd_stat_reviews.aspx\# ReviewofDefamationAct2005. At the time of writing, the call for submission was closed and no information is publicly available as to when the report can be expected. 
This text is taken from New Directions for Law in Australia: Essays in Contemporary Law Reform, edited by Ron Levy, Molly O’Brien, Simon Rice, Pauline Ridge and Margaret Thornton, published 2017 by ANU Press, The Australian National University, Canberra, Australia. 